\title{
Systematization of Cost Management Problems at Garment Enterprises of Ukraine
}

\author{
Nataliia Y. Radionova ${ }^{1, *}$ Lidiya V. Synytsia, $^{2, a}$ Svitlana O. Krasniuk ${ }^{1, b}$ \\ ${ }^{1}$ Kyiv National University of Technologies and Design, Kyiv, Ukraine \\ ${ }^{2}$ Interregional Academy of Personnel Management, Kiev, Ukraine \\ a'Email: L_sinitsa@ukr.net \\ bmail: krasniuk.so@ukr.net \\ *Corresponding author. Email: radionova_n@ukr.net
}

\begin{abstract}
It is noted that the problems of effective cost management exist at macro-, meso-and micro levels. The basic factors at macro-, meso- and micro level factors that negatively affect the cost management of Ukrainian garment enterprises are identified. The degree of influence of the specified factors on expenses of the enterprise is shown. The chain of values for the enterprises of the garment industry of Ukraine is clearly reflected. The ratio of the number and volume of sales of small and medium-sized enterprises of Ukraine engaged in the production of clothing in 2019 is researched, which confirms the hypothesis of low efficiency of Ukrainian small garment enterprises. The production of branded clothing by domestic enterprises based on toll raw materials is shown. The matrix method is used to focus on factors that have a significant impact on costs and are regulated by garment companies.
\end{abstract}

Keywords: costs, management problems, cost management, garment enterprises, negative factors

\section{INTRODUCTION}

The most important indicator of the activity of manufacturing enterprises is the profit, which depends on the amount of income and expenses. Obviously, the price of products also depends on the amount of costs. The consequence of the difficult economic situation in Ukraine is the low solvency of the population, which creates the preconditions for limiting the demand for products of domestic garment enterprises and necessitates the search for reserves to increase profitability by reducing costs. Thus, the rational formation of costs is a key factor for the effective operation of any enterprise.

Therefore, the enterprise must pay special attention to cost management for successful and long-term operation. To determine areas for improving cost management, the main problems that negatively affect the cost of garment enterprises and systematize them depending on the degree of possibility of their regulation by the enterprise should be considered.

\section{DETERMINATION OF NEGATIVE FACTORS}

A study of scientific sources shows that the problems of effective cost management exist at the macro and meso levels, as well as at the level of garment enterprises. To identify in more detail the problems that affect the costs of garment companies, it is proposed to analyse them taking into account the factors that exist at the macro, meso and micro level from the standpoint of the external and internal environment ("Table I").

Solving these problems requires a systematic, comprehensive approach. Of course, some of the macroeconomic factors of the external environment (low solvency of the population, high inflation, lack of real state support, high level of competition, etc.) are not subject to regulation at the enterprise level [1] However, some of the problems should be paid attention to the possibility of overcoming them.

Thus, problems such as the tax burden and tariffs for utility bills and energy can be defined as partially managed, as companies can apply different tax systems (general or simplified, VAT payer or not) and apply energy efficiency measures (energy saving technologies).

It should be noted that the garment industry is characterized by decentralization: each manufacturer tries to act independently, competing with others [2]. We believe that enterprises of textile production, production of clothing, leather, leather products and other materials need to work more closely with Ukrainian enterprises of related economic activities. 
TABLE I. THE DEGREE TO WHICH THE ENTERPRISE REGULATES PROBLEMS THAT NEGATIVELY AFFECT COSTS

\begin{tabular}{|c|c|c|c|}
\hline $\begin{array}{c}\text { Level of } \\
\text { occurrence }\end{array}$ & specified problems & Enterprise regulation & $\begin{array}{c}\text { The degree of influence } \\
\text { on the costs of the } \\
\text { enterprise }\end{array}$ \\
\hline \multicolumn{4}{|c|}{ Environment } \\
\hline \multirow[t]{6}{*}{ Macro level } & inflationary processes & unregulated & significant \\
\hline & tax burden & частково регульоване & middle \\
\hline & legislative acts & unregulated & middle \\
\hline & high tariffs for utility bills, energy carriers & $\begin{array}{l}\text { partly } \\
\text { regulated }\end{array}$ & significant \\
\hline & political circumstances & unregulated & middle \\
\hline & low solvency of a population & unregulated & middle \\
\hline \multirow[t]{5}{*}{ Meso level } & $\begin{array}{l}\text { weak level of interaction with domestic enterprises of related } \\
\text { economic activities }\end{array}$ & $\begin{array}{l}\text { partly } \\
\text { regulated }\end{array}$ & middle \\
\hline & $\begin{array}{l}\text { import dependence and high prices for imported raw materials, } \\
\text { materials, equipment, technologies }\end{array}$ & $\begin{array}{l}\text { partly } \\
\text { regulated }\end{array}$ & significant \\
\hline & $\begin{array}{l}\text { small share of medium-sized enterprises or small business } \\
\text { associations }\end{array}$ & $\begin{array}{l}\text { partly } \\
\text { regulated }\end{array}$ & middle \\
\hline & high level of competition & unregulated & middle \\
\hline & lack of real government support & unregulated & significant \\
\hline \multicolumn{4}{|c|}{ Internal environment } \\
\hline \multirow[t]{7}{*}{ Micro level } & $\begin{array}{l}\text { moral and physical wear and tear of equipment that has } \\
\text { exhausted its resource }\end{array}$ & regulated & significant \\
\hline & high staff turnover & regulated & significant \\
\hline & low competitiveness and high production cost & regulated & middle \\
\hline & hioh level of tollino & reoulated & sionificant \\
\hline & $\begin{array}{l}\text { poorly developed logistics infrastructure, which complicates the } \\
\text { sale of finished products }\end{array}$ & regulated & significant \\
\hline & insufficient protection of intellectual property rights for products & regulated & middle \\
\hline & insufficient popularity of domestic brands & regulated & significant \\
\hline
\end{tabular}

Thus, agriculture should provide textile production with the required amount of natural raw materials (flax, cotton, wool), and the chemical industry - with the artificial fibers for synthetic fabrics, special chemicals, dyes and more. Textile enterprises, in turn, produce many basic and auxiliary materials, such different types of technical production fabrics. The production of modern clothing models requires a wide range of high quality fabrics, which is not provided by the products of the textile industry of Ukraine. Domestic fabrics in terms of "price - quality" do not meet the needs of garment companies, which are more profitable to buy fabrics in China, Italy and other countries.

There is no production of equipment for garment enterprises in Ukraine today. The development of this type of economic activity requires significant financial investment and government support. The production of high-quality domestic equipment for the needs of garment production will have a positive impact on garment enterprises. Modern imported equipment and spare parts for it are not always financially available to Ukrainian companies, and those who have purchased imported equipment have to increase in production costs due to high depreciation.

Thus, the establishment of interaction of enterprises of related economic activities among Ukrainian enterprises will significantly reduce the import dependence of enterprises of this type of economic activity and will help to reduce the cost of production [3]. To implement this, it is advisable to use the approach proposed by M. Porter (the value chain), which at the meso level to optimize the activities of the garment industry is shown in "Fig. 1". 


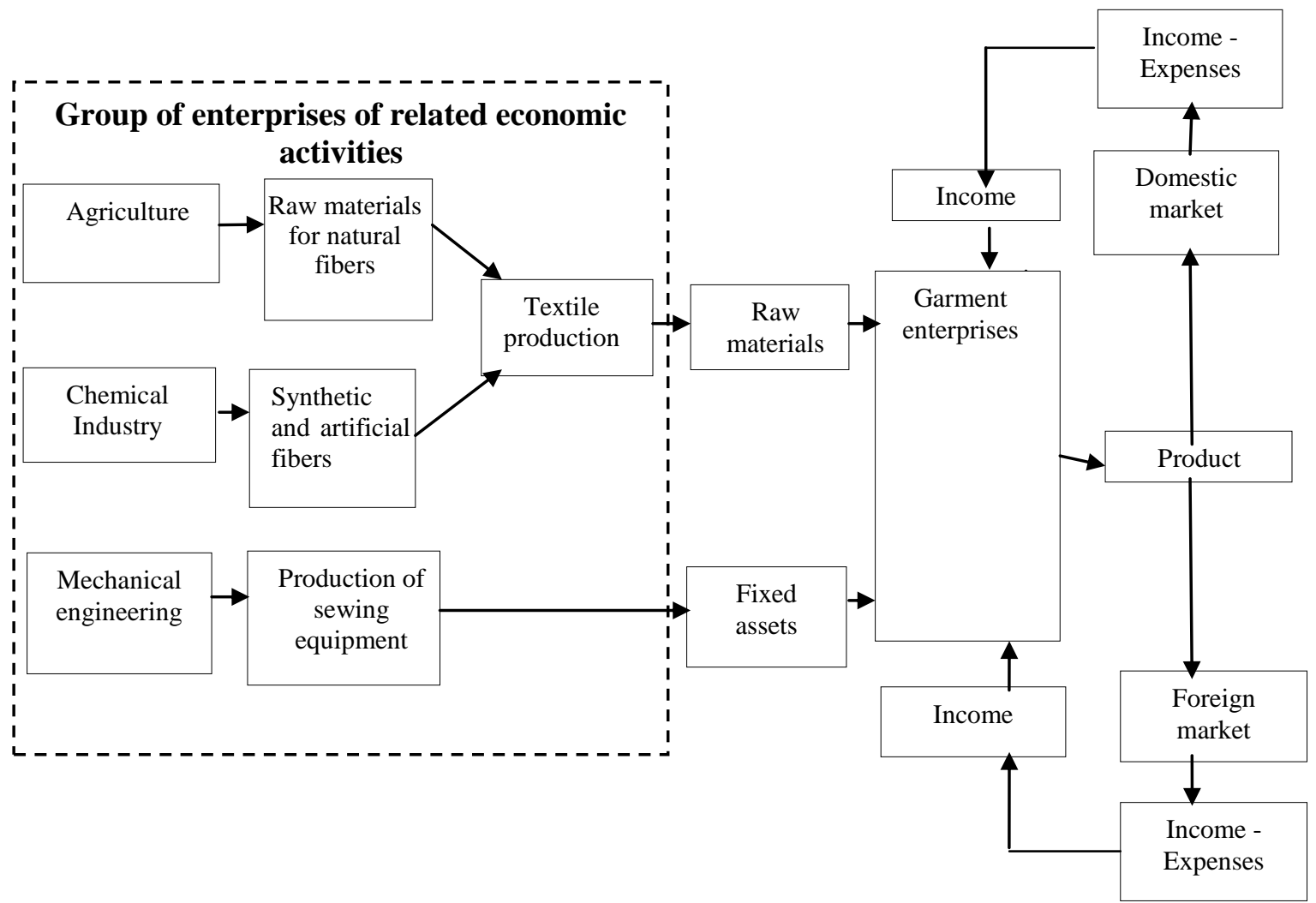

Fig. 1. The value chain for the garment industry of Ukraine.

There are business associations in Ukraine that can influence the activities of enterprises engaged in tailoring: the State Association "Ukrlegprom", "National Leather and Shoe Union of Ukraine" and trade and production concern "Textile Contact". However, these associations do not fully meet their purpose; their activity is not efficient enough, because, firstly, it is not able to solve the problems of enterprises of this type of economic activity at the macro level, and secondly, it is not able to create a single information space for enterprises that would promote their development and solve current problems [5]. In addition, most companies engaged in the textile, a. Source: developed by the authors of [4] clothing, leather and other materials industries are not members of business associations.

Among the problems of the meso level is the low share of medium-sized enterprises.

The study shows that medium-sized garment enterprises, which in 2019 accounted for about 2\% produce up to $73.3 \%$ of sold garments. Small enterprises, which are vast majority of enterprises of this type of economic activity (about 98\%) have a volume of sales of $26.7 \%$ in 2019 [6]. Schematically, this is shown in "Fig. 2".

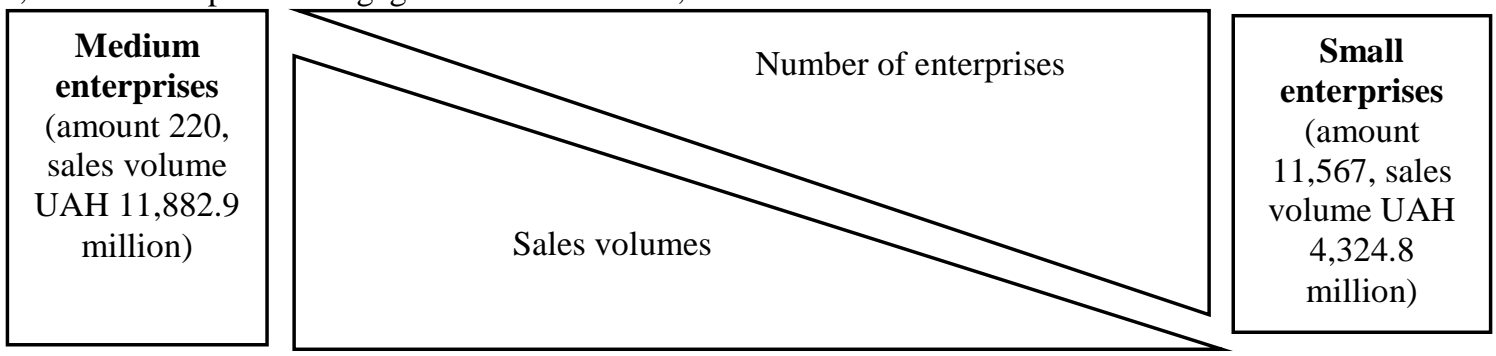

Fig. 2. The ratio of the number and volume of sales of small and medium-sized enterprises engaged in the production of clothing in 2019.

The study showed that medium-sized enterprises are more efficient for the production of clothing: they have
Source: developed by the authors according to to the data $[6,7]$ much higher sales, they provide more jobs and pay more taxes. 
In the domestic market, there is a monopolistic type of competition, when a relatively large number of small producers offer similar but not identical products. Monopolistic competition promotes the development of industry, dictates to producers the need for quality improvement of products, increasing the range, and so on. It should be noted that in monopolistic competition, product differentiation and brand formation are important. In addition, in the domestic market there is a significant amount of imported cheap goods (e.g. Chinese garments, second-hand), which makes the competitive conditions quite tough, especially in conditions of low purchasing power of the population.

Outdated equipment is a significant problem for Ukrainian garment companies. Historically, during the Soviet era, light industry was developed in Ukraine, which met the needs of the USSR with large production facilities. Due to lack of funds, lack of proposals of domestic engineering for special sewing equipment, uncertainty of prospects for garment production - a large number of garment companies today use equipment that remains from Soviet times and is obsolete, with low productivity and high energy consumption. This does not always make it possible to produce modern quality products and leads to an increase in its cost.

Previously, the light industry employed highly qualified personnel and labor dynasties. Today in the garment industry, there is a high turnover of staff, due to low wages. In addition, manufacturing professions in garment enterprises are not considered prestigious.
At the present stage, a significant number of domestic enterprises practice not only the production of full-cycle products, but also the execution of orders under schemes with toll raw materials (production from toll raw materials coming from abroad). The peculiarity of such schemes is that the importer retains ownership of raw materials and finished products obtained as a result of processing, and the processor only provides the necessary manpower and production capacity. At the same time, raw materials and patterns are provided by foreign companies-customers, and domestic garment factories only produce ready-made clothes, which can then be imported to the Ukrainian market under the brands of well-known brands. In other words, Ukraine uses only cheap labor, which does not contribute to the long-term development of garment production.

The specifics of garment production is that the consumers do not want to wear clothes of the same style. Therefore, clothing should be produced in small batches, from different fabrics and sold in different regions of the country. Insufficiently developed logistics for the regional distribution of goods is a serious problem for garment enterprises [8]. If earlier in the system of planned economy the classical chain "producer - wholesaler - retail" was established, now wholesale trade in the domestic market is practically absent. Sewing companies, due to the lack of practical experience in selling products in market conditions, need the services of an intermediary who could fill the gap between producers and consumers of garments.

TABLE II. PRODUCTION OF BRANDED CLOTHING BY DOMESTIC ENTERPRISES

\begin{tabular}{|c|c|c|}
\hline Enterprise & Location & Brands that are made from toll raw materials \\
\hline 1. Arnika & Chernivtsi city & Triumph \\
\hline 2. Balta sewing factory & $\begin{array}{l}\text { the city of Balta } \\
\text { (Odessa region) }\end{array}$ & $\begin{array}{l}\text { Benetton, Esprit, Kookai, Laura Ashley, Max } \\
\text { Mara, Mexx, Next, Steilmann, Top Shop, Wallis }\end{array}$ \\
\hline 3. Berdychiv sewing factory & $\begin{array}{l}\text { city of Berdychiv } \\
\text { (Zhytomyr region) }\end{array}$ & Licona, Peter Kaiser \\
\hline 4. Volodarka & the city of Vinnytsia & Hugo Boss \\
\hline 5. Gregory Arber & the city of Odessa & $\begin{array}{l}\text { Benetton, Conbipel, Esprit, Gerry Weber, } \\
\text { Mexx }\end{array}$ \\
\hline 6. Dana & city Kyiv & Iceberg, Sandro \\
\hline 7. Euro-Style & city Poltava & Frank Henke Mode GmbH, Franken Walder \\
\hline 8. Zoryanka & city Kirovohrad & $\begin{array}{l}\text { Gil Bret Gmвn \& Co.KGi, Betty Barclay Gmbh \& Co KG, Ленер Кардьє, } \\
\text { Frank Henke Moden, Model Service Etomilu s.r.l. }\end{array}$ \\
\hline 9. Kalyna & $\begin{array}{l}\text { the city of Chervonohrad } \\
\text { (Lviv region) }\end{array}$ & Triumph \\
\hline 10. Kremteks & $\begin{array}{l}\text { Kremenchuk } \\
\text { (Poltava region) }\end{array}$ & Betty Barclays, Vera Mont \\
\hline 11. Santa - Ukraina & $\begin{array}{l}\text { Pervomaisk } \\
\text { (Mykolaiv region) }\end{array}$ & BCBG, Grossa Moda, Laura Ashley, Mexx, \\
\hline 12. Trembita & Chernivtsi city & $\begin{array}{l}\text { Armand Thiery, Benetton, Celio, Fellini, Galeries Lafaytte, Gianni } \\
\text { Ferrucci, OVS, Prado }\end{array}$ \\
\hline 13. Trottola & the city of Lviv & New Look, Zara \\
\hline 14. Tul'chins'ka shveyna fabrika & Tulchyn city (Vinnytsia region) & $\begin{array}{l}\text { Diverse, Esprit, Grosso Moda, Karstadt, } \\
\text { Maratex, Mexx, Roxy, Staff, Walker }\end{array}$ \\
\hline
\end{tabular}


In today's world, clothing not only protects a person from adverse weather conditions, but is also an integral part of appearance, emphasizing individuality and status. Buyers are interested in a particular brand, want to wear things from well-known brands. A significant amount of branded clothing is being produced by domestic manufacturers according to tolling schemes ("Table II").

One of the problems of clothing production is insufficient protection of intellectual property rights. Thus, $12 \%$ of the surveyed managers from 25 surveyed garment enterprises admit the facts of copying industrial designs at enterprises, an even larger share of respondents $(18 \%)$ consider this fact a real problem.

Garment companies should involve in cooperation designers to create their own brands and marketers to promote them.

\section{MATRIX APPROACH FOR SYSTEMATIZATION OF FACTORS}

To determine the problems to which garment companies in cost management should pay attention in the first place, the matrix method is used ("Table III").

TABLE III. MATRIX OF EXTERNAL AND INTERNAL ENVIRONMENTAL FACTORS THAT NEGATIVELY AFFECT THE COSTS OF A GARMENT ENTERPRISE

\begin{tabular}{|c|c|c|c|}
\hline $\begin{array}{l}\text { Degree of regulation } \\
\text { Influence for expenses }\end{array}$ & Regulated & Partly regulated & Unregulated \\
\hline Significant & $\begin{array}{l}\text { - moral and physical wear and } \\
\text { tear of equipment that has } \\
\text { exhausted its resource; } \\
\text {-high staff turnover; } \\
\text {-low competitiveness and high } \\
\text { cost of production; } \\
\text { - high level of tolling; } \\
\text { - poorly developed logistics } \\
\text { infrastructure; } \\
\text {-insufficient popularity of } \\
\text { domestic brands }\end{array}$ & $\begin{array}{l}\text {-high tariffs for utility bills, energy } \\
\text { resources; } \\
\text {-import dependence and high prices for } \\
\text { imported raw materials, materials, } \\
\text { equipment, technologies }\end{array}$ & $\begin{array}{l}\text { - inflationary } \\
\text { processes }\end{array}$ \\
\hline Middle & $\begin{array}{l}\text {-insufficient protection of } \\
\text { intellectual property rights for } \\
\text { products }\end{array}$ & $\begin{array}{l}\text { - tax burden; } \\
\text {-a small share of medium-sized } \\
\text { enterprises or small business } \\
\text { associations; } \\
\text {-weak level of interaction with domestic } \\
\text { enterprises of related economic activities }\end{array}$ & $\begin{array}{l}\text {-political } \\
\text { circumstances } \\
\text {-high level of } \\
\text { competition; } \\
\text { imperfect legislation }\end{array}$ \\
\hline
\end{tabular}

Source: developed by the author

The matrix method allowed to systematize the factors that affect the costs of garment enterprises in order to focus the cost management system on those that, firstly, are affected at the micro level (are regulated by the enterprise), and secondly, have a significant impact on costs. Among such factors were noted: moral and physical wear of equipment that has exhausted its resource; high staff turnover; low competitiveness and high cost of production; high level of tolling; poorly developed logistics infrastructure; insufficiently promoted domestic brands. To eliminate these factors, garment companies need to work first.

We should not ignore the possibility of the company's influence on the factors that are listed as partially regulated: high tariffs for utility bills and energy; import dependence and high price for imported raw materials, equipment, technologies.

Having worked out the possibilities of influencing the factors that strongly influence costs, companies need to work on factors that have a medium impact on costs. Such factors that are subject to regulation at the micro level include insufficient protection of intellectual property rights. Domestic companies do not often issue intellectual property rights to industrial designs of developed products. Indeed, this is not traditional for Ukrainian enterprises. In addition, the preparation of a set of documents required for the issuance of a patent requires additional time. But in modern conditions, intellectual property is a necessary element to achieve a high economic level and strategic development of the enterprise.

Garment companies should also take into account factors that have an indirect impact on costs and are subject to partial regulation by companies. These include: tax burden; a small share of medium-sized enterprises or associations of small enterprises and a weak level of interaction with domestic enterprises of related economic activities. Part of the solution to this problem is possible through the integration of garment enterprises into a joint structure (business association) that will be able to solve the problems of garment enterprises at the meso and macro levels.

It is clear that the company cannot influence some factors. These include: inflationary processes, political 
circumstances, high level of competition, imperfect legislation.

\section{CONCLUSION}

The study allows us to conclude that garment companies need to form a cost management system that will solve the problem of their optimization, taking into account not only internal factors. Ukrainian garment companies operate in an environment where competition imposes severe restrictions on all its participants. For effective cost management, companies must take into account the negative factors of the macro-, meso- and micro levels. In order to increase the efficiency of cost management, a matrix method was proposed. It allowed to systematize the factors depending on the degree of their impact on the costs of the enterprise on the one hand, and depending on the possibility of their regulation by the enterprise on the other. Garment companies should focus primarily on the factors that are subject to regulation and have a significant impact on the formation of enterprise costs.

\section{References}

[1] Radionova N. Dual nature of industrial enterprise cost management system / N. Radionova, M. I. Skrypnyk, T. Voronkova // Baltic Journal of Economic Studies. - 2019. - Vol. 5, $\quad$ No. $\quad 2 . \quad-\quad-\quad$ P. $\quad 184-190$. http://www.baltijapublishing.lv/index.php/issue/article/view/652 $/ \mathrm{pdf}$

[2] Accounting and verification of sustainable enterprise development reporting / M. Skrypnyk, N. Radionova, T. Vlasiuk, S. Bondarenko, O. Grygorevska // IBIMA Business Review. - 2019. - Vol. 2019. - P. 1-10., https://ibimapublishing.com/articles/IBIMABR/2019/873407/

[3] Nataliia ORLOVA, Olena KOZYRIEVA, Nataliia KONDRATENKO, Militsa VOLKOVA, Oleg DIEGTIAR and Tykhon YAROVOY Enhancing Ukraine's Competitiveness in a Global Space Under Conditions of Sustainable Economic Development / N. ORLOVA, O. KOZYRIEVA, N. KONDRATENKO, M. VOLKOVA, O. DIEGTIAR, T. YAROVOY // Proceedings of the 34th International Business Information Management Association Conference (IBIMA) 13-14 November 2019 Madrid, Spain. - P. 7634-7651.

[4] Competitive Advantage: Creating and Sustaining Superior Performance. - New York: The Free Press, 1985 (2nd ed. New York: Free Press, 1998. — 592 p. — ISBN 978-0-68484146-5).

[5] M. Krasnyuk, S. Krasniuk (2020) Fraud detection in the business data as an important corporate anti-crisis method of audit // Modern challenges and current problems of science, education and production: intersectoral disputes [collection. science. mat.]: materials of the III international scientificpractical Internet conference (Kyiv, April 15, 2020). Kyiv, 2020. - p.14-16. https://openscilab.org/wpcontent/uploads/2020/04/aktualni_problemi_nauki_osviti ta_virobnictva_mizhgaluzevi_disputi_2020_04_15_tezy.pdf

[6] State Statistics Service of Ukraine [Electronic resource] / ofits. site.: www.ukrstat.gov.ua.

[7] Agency of industrial news [Electronic resource]: Official site. http://www.apn-ua.com
[8] Krasnyuk M. T., Hrashchenko I. S., Kustarovskiy O. D. and Krasniuk S. O. (2018), "Methodology of effective application of Big Data and Data Mining technologies as an important anticrisis component of the complex policy of logistic business optimization", Economies' Horizons, No. 3(6), pp. 121-136, doi: 10.31499/2616-5236.3(6). $2018 . \quad 156317$ http://eh.udpu.edu.ua/article/view/156317 